east coast of Scotland, and the possibility of the existence of outliers beneath the Glacial drift, is shown by the account (p. I3I) of the Cretaceous sandstone of Leavad, which was recognised by D. Tait in 1906 . This block, 240 yards in length, is used as a sandquarry, and rests on a green clay which, from its foraminifera, G. W. Lee regards as perhaps of Pliocene age. This in turn rests on boulder-clay, so that, as happens in Ostpreussen (NATURE, vol. Ixxxv., p. 470), local geology has been distinctly enriched by material imported during the Ice age.

The Geological Survey states that the issue of some of its colour-printed maps is delayed by work necessitated by the war; but it makes its own contribution to military needs in a pamphlet on "Sources of temporary water supply in the south of England and neighbouring parts of the Continent" (1914, price $2 d$.). The waters of sand-dunes, alluvium, and rivergravels are especially considered, and useful warnings are given as to pollution. It is remarked (p. Io) that a well sunk in sand or gravel on a chalk hill may lose its water if carried down to the surface of the porous chalk.

The proceedings of local societies, especially where universities are at hand to provide a stimulus, afford valuable supplements to the publications of the official surveys. The second part of vol. xv. of the Transactions of the Geological Society of Glasgow (price 7s. 6d.) forms an admirable example. All the papers record original observations in southern Scotland. Prof. J. W. Gregory (p. I74) treats of the red rocks of the Isle of Arran, which he regards as including Permian desert-beds at Brodick. These terrestrial deposits are, he urges, Lower Permian, and the appearance of conformity with the Keuper Marls above may be deceptive. G. W. Tyrrell (p. I88) describes critical sections in spots which he visited at Prof. Gregory's request, and is unable to discover any break in the sedimentation. The papers by $P$. Macnair, R. G. Carruthers, and J. E. Richey on the lower beds of the Carboniferous Limestone Series will do much to help workers in other districts, such as the north of Ireland.

G. A. J. C.

\section{EXPERIMENTAL BOTANY AT TRINITY COLLEGE, DUBLIN.}

T N "Notes from the Botanical School of Trinity 1 College, Dublin," No. 5, vol. ii., I9I5, Prof. H. H. Dixon gives experimental proof that morbid changes spread through plants from branches killed by heat. If a portion of a branch be killed by heat and the substances dissolved as the result of the heating be washed away, morbid changes only take place after some fourteen days. In cases where no steps are taken to remove the poisonous substances liberated by the heating, the branches above the heated portion show morbid changes in the course of five days. It is clear from the experiments that with the killing of the cells by heat, substances are liberated into the sap which contaminate the water supply to the living tissues above, and that the morbid changes are not due to the cutting off of the supply of water.

In a further paper in the same number of the "Notes" Prof. Dixon gives the result of his investigations into the nature of the changes which are produced in the sap by the heating of the branches. Sap was extracted by means of a centrifuge from pieces of branches, and was examined both fresh and after steaming for the acidity, colour, presence of oxydases and quantity of dissolved substances. The steamed sap showed marked acidity, a much higher percentage of dissolved substance-indicated by the depression of the freezing point-and a development of colour, any oxydase preNO. 2374, VOL. 95! sent being, of course, destroyed. The presence of poisonous properties was proved by placing leaves of Elodea canadensis in the steamed and in fresh sap, when it was noticed that lethal effects were produced quickly by the steamed sap, and that the leaves would not recover when placed in water.

In a paper on the tensile strength of sap, Prof. Dixon records tensions of about 207 atmospheres and ${ }_{132}$ atmospheres in a tube of sap collected from a branch of Ilex aquifolium. The former of these is probably the highest yet : ecorded for the cohesion of any liquid. The tensile strength of the sap of trees, like that of water; is considerable, but it is probably somewhat more stable under tension than pure water. Prof. Dixon and Miss Marshall have also examined the elements of the wood of trees in relation to the ascent of sap, and find no evidence to support Janse's hypothesis as to the intervention of the living cells in the ascent of sap in stems.

Mr. W. R. G. Atkins publishes a series of careful papers on oxydases and their inhibitors in plant tissues, and his work confirms that of Keeble, Armstrong, and Jones. The distribution of oxydases in the flowers of Iris has been particularly studied; when they are kept in darkness, the quantity of active peroxydases increases. In the Pogoniris group an active peroxydase is absent. The localisation of oxydases and catalases in some marine Algæ has also engaged the attention of the author.

\section{ENGINEERING, EDUCATION, AND RESEARCH. ${ }^{1}$}

RESEARCH.-Research for the solution of new problems is of great importance, but it is not a task for young and immature students. Many so-called researches, in which well-understood methods are applied to materials or subjects not themselves important, scarcely deserve the name. They amount to little more than class exercises. Most scientific societies receive papers in which a much over-elaborated description is given of known proceedings and precautions, in which the new results are of limited value without establishing any general law. But the value of real research, based on a clear formulation of a definite unsolved problem, cannot be overestimated.

Unfortunately, in engineering, the solution of unsolved but important problems is generally both difficult and expensive. Much, no doubt, is done by manufacturers who have a financial interest in the work. But their researches are, in general, not fully published. It is of great interest to the public at large and to other engineers that a scientific institution like this feels it part of its duty to advance knowledge by research, and is able to devote a fraction of its income for such researches as are beyond the means of private engineers. In most cases, a research committee of this institution begins by an investigation of what has been done befcre, and the summary of previous investigations which the institution publishes is not only a safeguard against mere repetition of experiment, but is valuable in itself. Prof. Martens, the director of the great State laboratory at Grosslichterfelde, has said that in four cases out of five when a manufacturer brings him a problem, it is found that it has already been solved somewhere by somebody.

The War and Engineering.-We meet in circumstances not foreseen a year ago. A war of unprecedented magnitude, extending over a vast area, has broken on us with the suddenness and fury of a tropical storm. We are already proud of the courage

1 From the presidential address ielivered to the Institution of Mechanical Engineers on April 16 by Dr. W. Cawthorne Unwin, F.R.S. 